\section{Moral responsibility}

SIR - In the leading article (Nature 25 October, p.692) on the expulsion of the exNazi scientist, Rudolph, from the United States, the statement is made that "scientific research is a neutral, amoral enterprise only in a free society, one with a democracy capable of exercising social judgement over the propriety of end uses". I would contend that you let us scientists off too easy, that we all have a moral responsibility, maybe even a duty, not to work on obviously immoral projects, such as, for example, those involving the murder of innocent people by chemical, biological, atomic-nuclear and even "conventional" weapons. Indeed, in the present international situation where warfare is not likely to be between individual soldiers but between peoples of contending states, it is the moral responsibility of scientists everywhere not to work on any project connected with waging war. I know the answer to this: that we in the democratic societies leave ourselves open to "nuclear blackmail"'. But are you so sure of that, as much as you seem to be unsure of the great possibility that the ludicrous, to say the least, build-up of weaponry will not lead to a nuclear-driven mass destruction?

PHILIPSIEKEVITZ

Rockefeller University,

1230 York Avenue,

New York, New York 10021-6399, USA

\section{Red Sirius}

SIR - In the light of the discussions in Nature of Homer's wine-dark sea during the past four months, it was almost inevitable that the old problem of the red colour of Sirius would arise sooner or later (Nature 6 September, p.8).

However, the problem is soluble, from the testimony of several independent observers.

Arguing for a red colour of Sirius, only two referees may be regarded as reliable: the Roman philosopher Seneca $(-70 \mathrm{BC})^{1}$ and the Alexandrine astronomer/ astrologer Ptolemy $(\sim \mathrm{AD} 150)^{2}$. Neither texts, however, gives particulars of how these observations were made. All other Greek and Roman texts often presented as additional evidence ${ }^{3}$, speak only of the "fires" and "flames" of Sirius as it scorches the Earth during the "Dog-days".

An Assyrian text (BM 118898) ${ }^{4}$, dating from the reign of Ashur-bel-kala ( $1070 \mathrm{BC})$, mentions a colour "red as molten copper", but here Sirius is clearly stated to be rising and was therefore observed close to the horizon. The same applies to the observations described by the Arab poet Ibn Alrakka (as preserved by al-Biruni $\left.(1000)^{5}\right)$.

Refuting such evidence are a number of contemporary texts citing a white or blue colour for Sirius. Astrological texts are very useful as stellar and planetary colours were closely observed for inferring future events. The Greek astrologer Hephaestion Thebanus $(\sim A D 400)^{6}$, citing older Egyptian sources (2BC), discusses the various prog nostications derived from the observed colours (golden, red, green and white) of Sirius at its heliacal rising. These colours clearly result from the effects of atmospheric extinction and scintillation on a white star near the horizon. Also, the Roman astologoer Manilius ( AD10) refers to the cold sea-blue quality of the rays of Sirius.

Most explicit are the observations found in the astronomical chapters of the ancient Chinese dynastical histories. Sima Qian $(\sim$ $90 \mathrm{BC})^{8}, \mathrm{Ma} \mathrm{Xu}(\sim \mathrm{AD} 100)^{9}$ and Li Shunfeng $(\sim \mathrm{AD} 635)^{10}$, discussing the colours of the planets and selected standard stars, all assign to Sirius a white colour.

This evidence clearly shows that Sirius has never been intrinsically red during the past few millennia and is in full accord with the present evolutionary phase of the Sirius-system.

Sonnenborgh Observatory, R.H. VAN GENT

Zonnenburg 2,

3512 NL Ultrecht,

The Netherlands

1. Seneca, Luc. Ann. Naturales Quaestiones I, 1.7 (transI. Corcoran, T.H.) Seneca Vol. VII (Loeb Classical Lib rary, 1971).

2. Ptolemy, C. Syntaxis Mathematica VIII, 1 (transl. Toomer, G.J.) Ptolemy's Almagest (Duckworth, London, 1984). See, T.J.J. Astr. Nachr. 229, 245 (1927).

4. Grayson, A.K. Assyrian Royal Inscriptions Vol, 2, 55 (Harrassowitz, Wiesbaden, 1976)

5. al-Biruni al-Athar al-Bakiya, 339 (transl. Sachau, E.C.) The Chronology of Ancient Nations, 338 (Allen, London, 1879, reprinted Minerva, Frankfurt, 1969).

6. Hephaestion Thebanus Apotelesmatica 1,23 (ed. Pingree, D.) (Teubner, Leipzig, 1973)

Manilius, M. Astronomica I, 409 (transl. Goold, G.P.) Manilius (Loeb Classical Library, 1977).

8. Sima Oian Shiji XXVII, 55 (transl. Chavannes, E.) Les Mémoires Historiques de Se-Ma-Ts'ien Vol III, 376 (Leroux, Paris, 1898, reprinted Brill, Leiden, 1967)

9. $\mathrm{Ma} \mathrm{Xu}$ in Ban Gu (ed.) Honshu XXVI, 25ab (ed. Buhzu, Changsha, 1900).

10. Li Shunfeng in Tai Zong (ed.) Jinshu XII, 2b (trans!. Ho Peng Yoke) The Astronomical Chapters of the Chin Shu, 125 (Mouton, Paris, 1966).

\section{Italian slur rebutted}

SIR - I was pleased to read in Nature (11 October, p.501) a news item wishing well to the new president of the Italian National Research Council (CNR). Indeed, Luigi Rossi Bernardi is a scientist first and a science administrator second, and his previous record is one of achievement through hard work, determination to assess quality and ability to develop rational policies. It is on these objective grounds that his appointment deserves praise. The sensitive reader will perceive this from the report. But it is unfortunate that in his opening paragraph Robert Walgate gives the impression that a major implication of the appointment is a transition from the "underdeveloped south" to the "better organized north". To this the sensitive reader may react emotionally. However, since Nature is a scientific journal, let us look at the issue scientifically.

In volumes 301-306 (1983) of your journal, there are eight papers from Italian institutions. Of these two are from the south, four from central Italy, one from the north. The eighth paper, interestingly, was a collaboration among laboratories in the south, centre and north (Catania, Perugia, Torino). Such a small sample has no claim to statistical significance, but it does not support the notion of a northsouth dichotomy with respect to research output, which is what CNR is about. More important, if we look for example to modern biology, it is quite obvious that the main thrust over the past twenty years has come from laboratories in Naples, which, together with other CNR institutes that have developed from them, have today the highest concentration in the country of research and training programmes in molecular genetics and molecular biology.

Nobody will deny the existence of a north-south gradient in economic development in Italy, the historical reasons for which are complex and defy any facile analysis. But it does not become Nature to perpetuate ill-founded clichés. The first medical school in the Western world was established in Salerno, near Naples, more than a thousand years ago. Today, among the hardest-working scientists some are Neapolitans working in Naples. One of the challenges facing the new president of CNR is to provide the physical facilities required for a more productive outcome of their efforts and of the talent of their young students. I am convinced that Luigi Rossi Bernardi will be equal to this challenge.

LUCIO LUZZATTO

Department of Haematology

Royal Postgraduate Medical School,

Ducane Road,

London W12 OHS, UK

SIR - It is unpleasant to read in a scientific journal such as Nature an article carrying racist and superficial judgements about Italy and the state of its science ("New Hope for Research Council" Nature 11 October, p.501).

Phrases such as "colourful Neapolitan presidency" or "underdeveloped south of Italy" betray profound arrogance and ignorance. You also say that the new CNR president "as a scientist" promises a scientific management of the research council that clashes with his political friendships (a truly scientific asset) and the most incredible statement of all - ". . . he comes from a medical department, medics being 'the strongest mafia - in the best sense [my italics] in the Italian universities" ". I agree on the strength of that particular mafia. But I am sceptical of any "best sense" underlying that lobby. Mafia is mafia and no benefit can come from it to Italian science.

FRANCESCO IZZO

Casella Postale 87,

I-05018 Orvieto, Italy 